\title{
POLA PENGEMBANGAN POTENSI KECERDASAN EMOSIONAL DAN SPIRITUAL ANAK PENYANDANG AUTISME
}

\author{
Zainal Abidin \\ Institut Agama Islam Negeri Metro \\ E-mail: zainaltob@yahoo.co.id \\ Isti Fatonah \\ Institut Agama Islam Negeri Metro \\ E-mail: Isti.fatonah67@gmail.com \\ Linda Septiyana \\ Institut Agama Islam Negeri Metro \\ E-mail: Lindaseptiyana@metrouniv.ac.id
}

Article received: 19 April 2019, Review process: 27 February 2019

Article published: 30 September 2019

\begin{abstract}
This research is a qualitative field research which attempts to analyze the development of emotional and spiritual intelligence of Autism Persons at Autism Service Center (PLA) Metro. This study seeks to answer the question of how the pattern of developing emotional intelligence and spiritual intelligence of children with autism inpla Metro. To make it easier to answer and find the research question, in this study using several methods including dirFect observation, in-depth interviews, and studying documentation based on data obtained in the field. The results of this study indicate that the pattern of development of emotional intelligence and spiritual intelligence of children with autism is indeed somewhat different from normal children, even between autistic one with autism, because it turns out there are differences in the types of autism itself. In general, the pattern of intelligence development of autistic children requires special handling, by combining it with several well-known therapeutic methods in the handling of autism such as the ABA (Applied Behavior Analysis) method, physiotherapy, speech therapy, out door therapy, and others. The therapy method is combined with a religious approach to get emotional and spiritual intelligence, by getting used to autism and at the same time the therapist always prays in starting his therapeutic activities. This habituation is a reflection of the awareness of the "God Spot", in each of their activities, and is an application of spiritual quality, dzikir and thought, as well as an application of harmony, and harmony in an integrated manner, in the process of therapy for persons autism.
\end{abstract}

Key Word: Emotional Intelligence, Spiritual Intelligence, and Autism

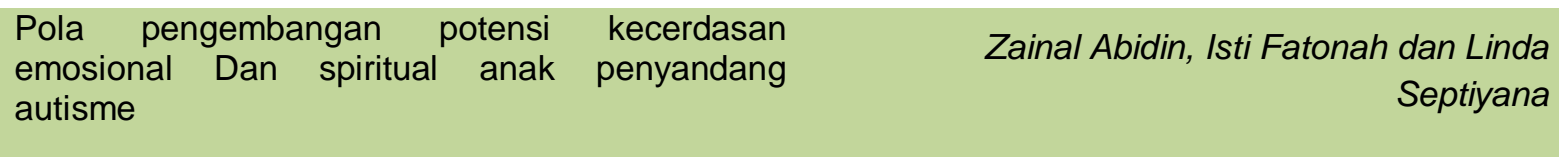




\section{Abstrak}

Penelitian yang dilakuakan adalah penelitian kualitatif yakni dengan melakukan penelitian lapangan. Untuk menganalisis pengembangan kecerdasan emosi dan spiritualn dari autism orang pada autism pelayanan terpadu (PLA) metro. Kajian ini bertujuan untuk menjawab pertanyaan tentang bagaimana pola mengembangkan kecerdasan emosional dan spiritual intelijen anak dengan autism inpla metro.Untuk mempermudah untuk menjawab dan menemukan penelitian pertanyaan, dalam kajian ini dengan menggunakan beberapa metode termasuk pengamatan langsung, wawancara mendalam, dokumentasi dan disebabkan kamu tetap mempelajarinya berdasarkan data yang diperoleh di lapangan. Hasil studi ini menunjukkan bahwa pola pengembangan kecerdasan emosional dan spiritual intelijen anak dengan autism adalah sesungguhnya agak berbeda dari normal anak-anak, bahkan antar dengan high-functioning satu dengan autism, karena ternyata sebanyak adalah perbedaan jenis autism itu sendiri. Secara umum , pola pengembangan kecerdasan anak autis lain dibutuhkan penanganan khusus, dengan menggabungkan dengan beberapa metode terapi well-known dalam penanganan autisme seperti aba metode analisis perilaku diterapkan, menjalani fisioterapi, terapi pidato, terapi pintu keluar, dan lain lain. Metode terapi yang dikombinasikan dengan pendekatan keagamaan juga untuk mendapatkan kecerdasan emosi dan rohani , dengan mendapatkan digunakan untuk autisme dan pada saat yang sama terapis selalu berdoa untuk menghidupkan kegiatan terapi nya. .Ini kebiasaan adalah menunjukkan pengetahuan dan kesadaran masyarakat dalam setiap kegiatan mereka, dan aplikasi kualitas rohani, dzikir dan berpikir, serta aplikasi harmoni, dan harmoni dalam sebuah paket yang terpadu, dalam proses terapi bagi orang orang yang autisme.

Kata Kunci: Kecerdasan emosional, kecerdasan spiritual dan autisme

\section{PENDAHULUAN}

Dalam perspektif psikologi perkembangan terdapat gangguan perkembangan kompleks yang muncul gejalanya pada usia perkembangan anak sebelum berusia tiga tahun. Gejala gangguan perkembangan tersebut disebut dengan autisme, yakni gangguan neurologi pervasif yang terjadi pada aspek neorolobiologis otak dan mempengaruhi proses perkembangan anak, akibat autisme ini anak cenderung tidak dapat secara otomatis belajar berinteraksi dan berkomunikasi dengan lingkungan sekitar, dan terlihat hidup dengan dunianya sendiri. Bagi penyandang autisme membutuhkan perhatian khusus untuk mengembangkan potensi kecerdasannya terutama kecerdasan yang berkaitan dengan interaksi lingkungan sekitar yaitu kecerdasan emosional dan spiritual, disebabkan adanya fenomena ganggguan kecerdasan akibat menderita gejala autisme.

Istilah kecerdasan emosional dan spiritual (Emotional and Spiritual Quotient) atau disingkat ESQ, baru muncul sekitar tahun 1990, setelah dalam dunia pendidikan konsep

Pola pengembangan potensi
emosional Dan spiritual anak penyandang
autisme


kecerdasan hanya didominasi oleh kecerdasan intelegensi (IQ). Menurut (Hamzah: 2008) kecerdasan emosional dan spiritual pertama kali dipopulerkan oleh Peter Salovey dan John Mayer yang menjelaskan tentang berbagai jenis emosi dan potensi spiritual yang dimiliki oleh manusia, dan menentukan keberhasilan seseorang dibandingkan dengan kecerdasan intelegensi. Menurut (Ari Ginanjar Agustian: 2001), ESQ merupakan metode dan sekaligus konsep pasti jawaban dari kekosongan batin sang jiwa. ESQ juga dapat menghambat segala hal yang kontraproduktif terhadap kemajuan umat manusia. Begitu juga dalam konteks psikologi klinis, pengembangan potensi kecerdasan emosional dan spiritual memberikan pengaruh yang besar bagi proses terapi bagi anak yang berkebutuhan khusus, termasuk penyandang autisme.

Data kuantitatif anak-anak penyandang autisme di dunia dan khususnya di Indonesia cukup banyak. Data dari UNESCO pada tahun 2011 mengindikasikan bahwa 6 diantara 1000 orang terdapat penderita autisme. Sedangkan di Indonesia hingga tahun 2013 diperkirakan terdapat lebih dari 112.000 anak yang menderita autisme dalam usia 5-19 tahun. Perdebatan tentang penyebab autisme pada anak sangat beragam, maka penangan terhadap penyandang autisme juga sangat beragam bisa melalui terapi psikologis, maupun melalui pendidikan khusus penyandang autisme, dan memasukkan penyandang autisme sebagai anak-anak yang berkebutuhan khusus.

Sebagian ahli memandang bahwa autisme adalah kelainan perkembangan sistem saraf pada seseorang yang disebakan oleh faktor hereditas (Handojo, 2015:3). Sementara pendapat lain menyatakan bahwa autisme bukanlah penyakit kejiwaan karena ia merupakan suatu gangguan yang terjadi pada otak sehingga tidak dapat berfungsi selayaknya otak normal, dan yang paling umum menganggap bahwa autisme merupakan bagian dari kelainan spektrum Autisme atau Autism Spektrum Disorder (ASD) dan merupakan salah satu dari lima jenis gangguan di bawah payung Gangguan Perkembangan Pervasif atau Pervasive Development Diosrder (PDD). Data penelitian juga menunjukkan bahwa gejala autisme lebih banyak terjadi pada bayi laki-laki dari pada bayi perempuan. Data tersebut diperoleh pada tahun 2002, pada anak-anak prevelansinya naik $60 \%$ sementara pada perempuan hanya $48 \%$.

Kata Autis berasal dari bahasa Yunani "Auto" berarti sendiri yang ditujukan bagi seseorang yang menunjukkan gejala "hidup dalam dunianya sendiri". Pada umumnya

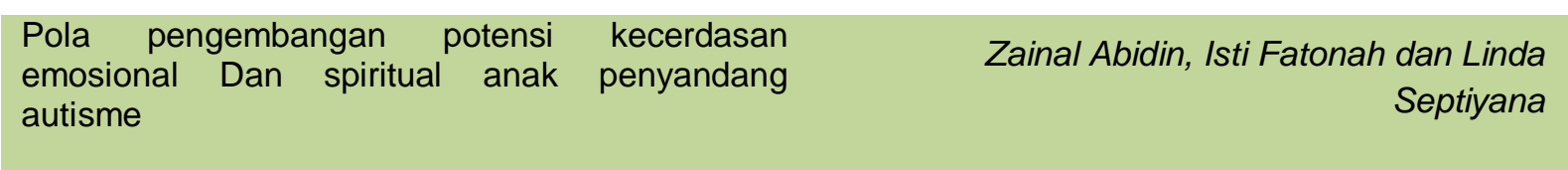


penderita autisme mengacuhkan suara, penglihatanatau kejadian yang melibatkan mereka. Dalam kronologis historis, istilah autisme atau autisma pertama kali muncul pada tahun 1938 bardasarkan laporan penelitian yang dilakukan oleh dr. Leo Keanner (seorang Dokter spesialis Penyakit Jiwa) melaporkan bahwa dia telah mendiagnosa dan mengobati pasiendengan sindroma autisme yang dia sebut sebagai "Infantile-Autisme". Dan untuk menghormati penemunya kadang autisme juga disebut sebagai "Sindroma Keanner", dengan gejala kesulitan menggunakan bahasa, berperilaku berulang-ulang serta bereaksi tidak biasa terhadap rangsangan sekitarnya (Dimah, 2002:6). Leo Keanner merupakan psikiater dari Harvard University, dalam tulisannya Autistic Disturbance of Affective Contact, tahun 1943 melaporkan bahwa berdasarkan hasil pengamatannya terhadap 11 penyandang autis menunjukkan gejala kesulitan berhubungan dengan orang lain, mengisolasi diri, perilaku yang tidak biasa dan cara berkomunikasi yang aneh dan dapat menimpa semua golongan masyarakat kaya atau miskin, di desa ataupun kota.

Dalam literatur lain Ayu Wulandari menyatakan bahwa autisme merupakan perkembangan kekacauan otak dan gangguan pervasive yang ditandai dengan terganggunya interaksi sosial, keterlambatan dalam bidang komunikasi, gangguan dalam bermain, bahasa, perilaku, gangguan perasaan emosi, interaksi sosial, gangguan dalam perasaan sensoris serta tingkah laku yang berulang-ulang. Gangguan tersebut menyebabkan seseorang menarik diri dari dunia luar dan menciptakan fantasainya sendiri. Sejak tahun 1950 para professional di Amerika dan Eropa Barat, sudah memulai peduli dengan autisme. Sedangkan di Indonesia baru menghangat pada decade tahun 1980 an. Kebanyakan intelegensia anak autis rendah. Namun demikian $20 \%$ dari anak autisme masih mempunyai IQ>70. Kemampuan khusus masih mereka miliki walaupun berada dalam tingkat rendah, seperti membaca, berhitung, menggambar, melihat panggalan, mengingat jalan dan sebagainya. Anak autis masih mempunyai kemampuan tersebut, tetapi tidak sampai sperti anak Down Syndrome yang idiot atau anak yang gerakan ototnya kaku, pada anak dengan kelainan jaringan otak. Karena itu, penyadang autisme berbeda dengan penyandang Down Syndrome yang berada dalam level Idiot. Penyandang autis masih berada pada level IQ>70, yang memungkinkan untuk diterapi dengan mengintefsifkan kerja emosi dan spiritualnya, yakni dengan terapi untuk menstimulasi potensi kecerdasan emosional dan kecerdasan spritualnya, dengan berbagai pendekatan yang

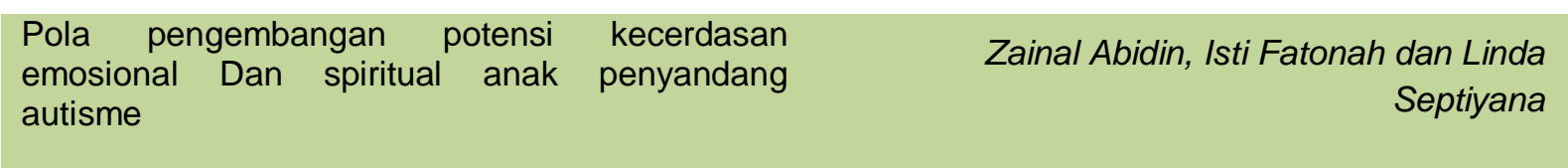


digunakan dalam terapi autisme, untuk memperbaiki kendala gangguan mental yang mereka alami, agar menjadi normal.

Beberapa pakar mensinyalir bahwa perubahan genetik merupakan penyebab ganggguan autis. Namun beberapa pakar menyatakan kurang yakin dengan penjelasan dan lebih mengarah pada isu pengaruh lingkungan, seperti diungkapkan oleh Dr. Thomas Insel, Direktur National Institute of Mental Health, Amerika Serikat. Pemicu utama timbulnya gejala autisme menurut para ahli terjadi pada masa kehamilan atau pada bulan-bulan awal kehidupan bayi, dan akibat pola makan sang ibu dan paparan lingkungan, atau terjadinya infeksi pada bayi yang diduga berpengaruh besar terhadap timbulnya autisme.

Bagi penyandang autisme diperlukan pembinaan dan terapi untuk menstimulir mentalnya dengan memberikan pendidikan yang berorientasi pada pengembangan potensi kecerdasan yang dimiliki penyandang autisme. Meskipun hal itu membutuhkan waktu yang panjang dan biaya yang tidak sedikit. Dalam realitasnya banyak professional di dunia yang bekerja dengan prestasi tinggi, dulunya adalah penyandang autisme yang berhasil diarahkan sesuai dengan kemampuan minat dan bakatnya, setelah melalui sejumlah pendidikan khusus dan terapi autis (Tilton, 2013:78).

Ada beberapa macam metode penanganan atau terapi autisme. Pertama, educational treatment, yaitu terapi dengan menjalankan konteks pendidikan. Kedua, pendekatan developmental yakni pendekatan perkembangan fisik dan mental anak yang dikaitkan dengan proses pendidikan. Ketiga, "Biological Treatment" dengan cara memberikan vitamin, diet dan pemberian obat-obatan untuk mengurangi perilaku-perilaku tertentu (agresivitas, hiperaktif, melukai diri sendiri dan sebagainya). Keempat, "Speech-Language Therapy" (terapi wicara), dan komunikasi atau (PECS/Picture Exchange Communication System), meliputi kegiatan melatih konunikasi secara verbal dan personal atau dengan menggunakan bahasa isyarat, strategi visual menggunakan gambar dalam berkomunikasi dan pendukung komunikasi lainnya (Ginanjar, 2012). Keenam, pelayanan autisme yang intensif, meliputi kerja tim dari berbagai disiplin ilmu yang memberikan intervensi baik di rumah, sekolah maupun lingkungan sosial lainnya.

Gayatri Pamoedji (2010:15) mengatakan bahwa Strategi dan model terapi bagi penyandang autisme banyak sekali ragamnya disamping yang telah disebutkan di atas, ada

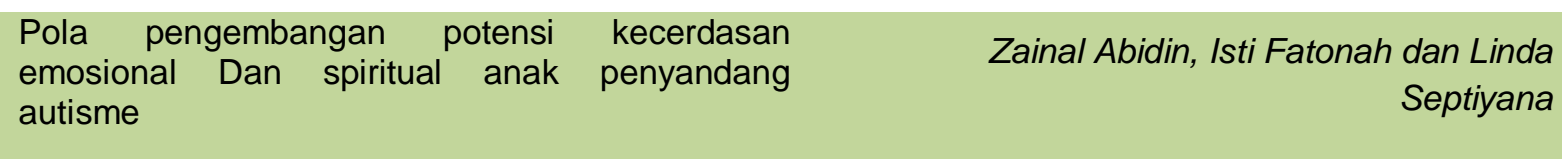


juga beberapa terapi penyandang autisme, yang dilakukan dengan "terapi lumba-lumba" yang sering ditayangkan di televisi atau media sosial lainnya, dan mungkin kedepannya akan banyak ditemukan model atau strategi terapi bagi penyandang autisme, mengingat fenomena terakhir mengindikasikan terjadinya gejala peningkatan penyandang gangguan autisme di dunia.

Beberapa jenis terapi berkembang secara dinamis, ada yang bersifat tradisional dan telah teruji dari waktu ke waktu, sementara terapi lain baru muncul atau ditemukan. Para ahli semua sependapat bahwa penderita autis harus ditangani sejak dini, dan diberikan treatmen yang komprehensif, yang meliputi terapi wicara (Speech Therapy), terapi okupasi (Occupacional Therapy) dan terapi ABA (Applied Behavior Analysis) untuk mengubah serta memodifikasi perilaku autism (Prasetyo, 2005:9).

Sebagai kota pendidikan di propinsi Lampung, tampaknya kota Metro juga mempunyai pusat layanan penyandang (penderita) Autisme. PLA (Pusat Layanan Autis) telah beroperasi dalam memberikan layanan pendidikan anak-anak penyandang Autisme di kota Metro Lampung. Hal ini juga mengindikasikan kepedulian pemerintah kota Metro terhadap masalah autisme di wilayah itu, termasuk perhatian terhadap penyandang disabilitas lainnya, dengan membangun sekolah-sekolah luar biasa yang diperuntukan bagi anak-anak berkebutuhan khusus. Penelitian ini berusaha meneliti pola pengembangan potensi kecerdasan emosional dan spiritual bagi anak penyandang autisme di kota Metro. Hal ini menarik untuk diteliti karena keberadaan penyandang autisme di dunia dalam dasawarsa terakhir mengindikasikan adanya peningkatan jumlahnya. Penelitian ini akan mengkaji tentang masalah autisme dan upaya pengembagan potensi kecerdasan emosional dan spiritual bagi anak-anak yang menyandang autis di Pusat Layanan Autis (PLA) kota Metro.

Berdasarkan uraian dalam latar belakang masalah penelitian, yang menjelaskan tentang pentingnya pengembangan kecerdasan emosional dan spiritual bagi penyandang autisme,maka dalam penelitian ini dapat dirumuskan masalah utama penelitian adalah Bagaimana pola pengembangan potensi Kecerdasan Emosional dan Kecerdasan Spritual anak penyandang autisme pada Pusat Layanan Autis (PLA) di Kota Metro Lampung

Penelitian ini didesain dengan beberapa tujuan utama. Pertama, untuk menganalisis berbagai permasalahan tentang autisme yang meliputi pengertian, gejala, penyebab dan

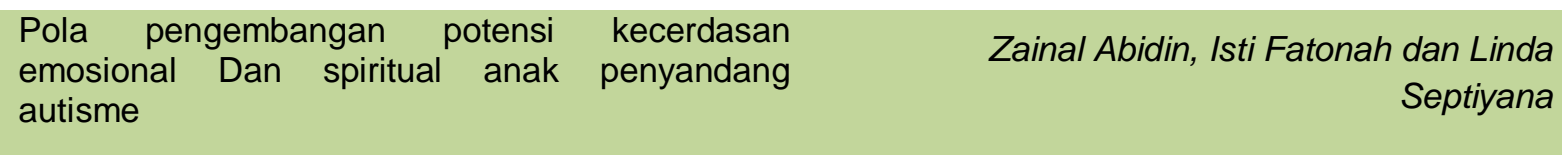


berbagai metode terapi yang berkaitan dengan upaya normalitas mental penyandang autisme. Kedua, penelitian ini juga bertujuan untuk mengetahui pola pengembangan potensi kecerdasan emosional dan spiritual penyandang autis di Pusat Layanan Autis di kota Metro Lampung. Ketiga, penelitian bertujuan mengembangkan metode pendidikan bagi anak-anak berkebutuhan khusus atau penyandang disabilitas mental dan fisik terutama anak-anak autis.

\section{METODOLOGI}

Penelitian ini didesain sebagai penelitian kualitatif lapangan, untuk mengetahui pola pengembangan potensi kecerdasan emosional dan spiritual bagi penyandang autisme pada Pusat Layanan Autis (PLA) di Kota Metro Lampung. Obyek penelitian anak penyandang autism yang sedang menjalani proses pembinanan atau terapy dilembaga tersebut yakni di Pusat Layanan Autis (PLA) kota Metro yang berlokasi di daerah 24 kota Metro. Penelitian ini, sekaligus meneliti akan tentang proses pembelajaran dalam rangka pengembangan potensi kecerdasan emosional dan spiritual bagi anak-anak penyandang penyandang autisme, termasul melihat metode yang digunakan oleh guru atau pembinanya dalam menangani berbagai masalah yang dihadapi anak autis di Pusat Layanan Autis Kota Metro Lampung.

Menurut Burhan Bungin (2010:59-60), jenis penelitian kualitatif lapangan dapat dipetakan menjadi beberapa varian antara lain, pertama, penelitian kualitatif eksploratifdeskriptif yang berusaha menggali secara deskriptif fenomena yang ada dilapangan. Kedua, penelitian jenis kualitatif survey lapangan, yang berusaha melakukan pendalaman realitas berdasarkan data-data obyektif yang ada di lapangan dan dianalisa berdasarkan kecenderungan dominan obyeknya. Berdasarkan jenis penelitian tersebut, maka peneliti berusaha memadukan kedua jenis penelitian yakni jenis penelitian kualitatif lapangan eksploratif-deskriptif dengan jenis penelitian survey lapangan. Penggabungan jenis penelitian lapangan tersebut diperkuat oleh pendapat Lexy J. Moeleong (2002:9) yang menyatakan bahwa jenis penelitian kualitaif lapangan tidak bisa dilepaskan dari paradigma dan pendekatan fenomenologis yang menjadi setting dasar penelitian, yang digunakan untuk melihat berbagai gejala yang ada dari berbagai sudut pandang dan analisis secara komprehensif terhadap kenyataan sosial yang ada, tanpa terbelenggu oleh variabel-variabel yang sering membatasi penelitian, sehingga hasil penelitian yang dihasilkan lebih bersifat lebih alamiah dan mendalam, karena ada usaha menghindari intervensi peneliti terhadap

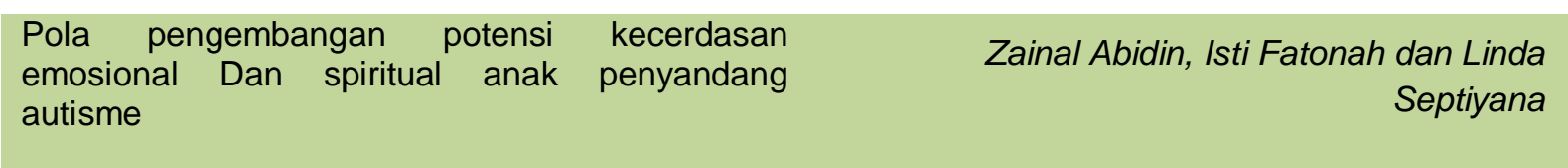


obyek yang diteliti. Memperhatikan statemen tersebut penelitimelak ukan analisis secara komprehensif mengenai berbagai permasalahan yang dihadapi oleh anak-anak penyandang autis yang sedang menjalani proses pendidikan dan pembinaan mental di PLA (Pusat Layanan Autis) kota Metro, terutama dalam rangka pengembangan potensi kecerdasan emosional dan kecerdasan spiritualnya, serta bebagai problematika yang dihadapi oleh guru dalam membina anak-anak autis di lembaga tersebut.

Penelitian ini dilakukan pada anak-anak penyandang Autis di Kota Metro Lampung yang sedang menjalani pendidikan atau terapi di Pusat Layanan Autis. Sesuai dengan desain penelitian kualitatif lapangan yang membutuhkan metodologi khusus dalam pengumpulan data dan teknik analisa datanya. Karena jenis penelitian ini adalah deskriptif kualitatif maka analisa datanya digunakan beberapa metode antara lain adalah metode observasi langsung untuk mengamati berbagai fenomena yang terjadi dilapangan penelitian (Vredenbregt:1981). Metode observasi dimaksudkan untuk mengatahui obyek penelitian yakni dengan mengamati fenomena yang ada di lapangan terutama perilaku anak autis, dan melikah pola penangannya di lembaga tersebut. Kemudian penelitian ini juga menggunakan metode wawancara mendalam (in-depth interview) dan analisis dokumenter untuk menggali informasi yang berguna untuk menganalisa data-data penelitian yang dibutuhkan yang berfungsi memperdalam validitas isi penelitian (Koentjaraningrat: 178). Wawancara dilakukan dengan direktur atau Kepala Pusat Layanan Autis (PLA) kota Metro, dan guru-guru yang bertugas dalam lembaga tersebut, dan metode dokumentasi dipergunakan untuk mendapatkan data-data otentik berdasarkan dukumen yang tersedia di tempat penelitian, antara lain tujuan serta sejarah PLA (Pusat Layanan Autis) Kota Metro, serta fluktuasi jumlah anak autis yang dibina di lembaga itu.

\section{HASIL DAN PEMBAHASAN}

Secara historis PLA (Pusat Layanan Autis) Kota Metro mulai dibangun sejak tahun 2013, dan merupakan bantuan dari Direktorat Pendidikan Layanan Khusus (PK-LK) Pendidikan dasar melalui APBN dan APBD II. Bantuan berupa Gedung, sarana dan Prasarana serta alat-alat penunjang pembelajaran. PLA (Pusat Layanan Autis) kota Metro berlokasi di Jalan Raya Stadion Kelurahan Tejosari Kecamatan Metro Timur Kota Metro, dan secara resmi beroperasi pada bulan Januari 2015, serta langsung menerima Anak penyandang

$\begin{aligned} & \text { Pola pengembangan potensi } \\ & \text { emosional } \text { kan spiritual anak }\end{aligned}$ penyandang
autisme


spektrum autis. Hingga tahun 2018 ini PLA Kota Metro telah banyak melakukan kerja-kerja sosial yang positif dalam penanganan anak penyandang autis. Dalam proses penanganan anak autis di PLA kota Metro terbagi dalam beberapa tingkatan, mulai dari anak usia TK (Taman Kanak-Kanak), SD, SMP dan SMA. Permasalahan autis dalam konteks ini mulai mendapatkan perhatian dari pemerintah dan mendapatkan respon yang positif dari masyarakat kota Metro dan sekitarnya yang mempunyai anak-anak berkebutuhan khusus (ABK) yang telah berjalan sejak tahun 2015 .

Secara umum PLA merupakan lembaga yang memberikan layanan berupa asesmen, intervensi terpadu, pendidikan transisi kepada Anak Spektrum Autis (ASD) dengan layanan selama satu tahun untuk selanjutnya akan disertakan ke sekolah-sekolah yang menyelenggarakan pendidikan khusus dan layanan khusus dengan melihat progres perkembangan kemampuan anak apalbila ternyata anak tersebut belum dapat mengikuti maka akan kembali mendapatkan layanan lanjutan di PLA sesuai dengan kebutuhan si anak tersebut. Layanan perlu dilakukan untuk meminimalisir hambatan atau gangguan perilaku repetitive (mengulang-ulang), agresif, gangguan kesimbangan dan lain-lain, membentuk perilaku positif, adaptif dengan lingkungan, meningkatkan komunikasi, membentuk kemandirian anak dan mendukung kemampuan dasar akademis.

Pusat layanan autis kota Metro memberikan layanan bagi putra-putri warga Metro dan sekitarnya yang memilik problem gangguan spektrum autis, dan diprioritaskan untuk anak berusia 2 sampai dengan 12 tahun. Jumlah anak autis di kota Metro sejak tahun 2014 sekitar 58 anak, sehingga PLA kota Metro keberadaannya sangat strategis dan sangat di perlukan untuk membantu mengatasi problem-problem yang dihadapi anak autis. Secara fakta bahwa terdapat peningkatan yang cukup signifikan penyandang autis di kota Metro, berdasarkan antuiasme warga pendaftar yang melakukan pendaftaran untuk memasukkan anaknya pada PLA Kota Metro, yang telah masuk pada taraf daftar tunggu (waiting list).

Penyandang autis bisa dikategorikan sebagai Anak Berkebutuhan Khusus (ABK), maka keberadaan PLA Kota Metro diharapkan mampu memberikan yalanan asesmen dan intervensi dengan tujuan memberikan pembelajaran untuk memperoleh kesiapan dalam mengikuti pendidikan dan pengajaran. Dengan model tersebut anak diharapkan benar-benar siap dan dinilai cuku mampu untuk melanjutkan pendidikannya pada satuan pendidikan umum

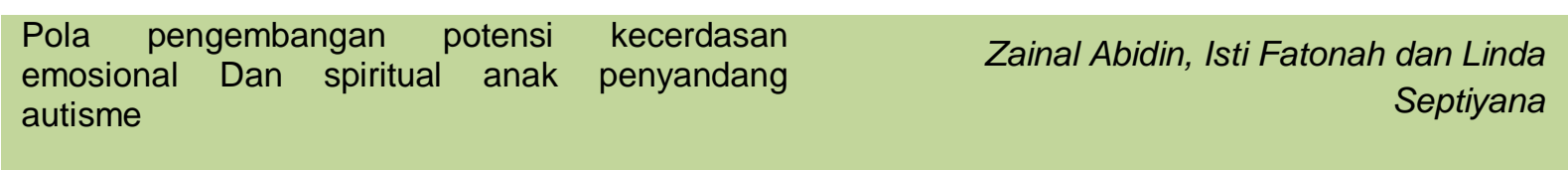


maupun kejuruan. Program pendampingan dalam menangani anak autis di PLA kota Metro melayani anak autis dengan segala kendala yang dihadapinya dengan memberikan bantuan dan bimbingan sehingga menjadi sosok yang percaya diri, berkemampuan sama seperti anakanak yang lain. Secara nasional, ada peringatan anak autis, yang dilakukan setiap tanggal 2 April, dan diselenggrakan beberapa kegiatan untuk mendukung layanan bagi penyandang autis di seluruh Indonesia., dengan memberikan pendidikan inklusi bagi anak-anak autis.

Pusat Layanan Autis (PLA) Kota Metro adalah unit Pelayanan Teknis Daerah (UPTD) pendidikan yang memiliki tugas dan fungsi memberikan dukungan layanan dalam perspektif pendidikan untuk anak-anak autis di masyarakat. Tujuan PLA Kota Metro memberikan kesempatan kepada anak autis untuk memperoleh layanan pendidikaan dan bimbingan anak autis antara lain. Pertama, memberikan kesempatan kepada anak autis untuk memperoleh layanan asesmen dan intervensi agar mereka memperoleh kesiapan untuk mengikuti pendidikan pada satuan pendidikan umum satuan pendidikan kejuruan, satuan pendidikan khusus. Kedua, meminimalisir hambatan atau gangguan (perilaku repetitive, agresif, lack of attention, gangguan keseimbangan dan lain-lain) anak autis. Ketiga, membentuk perilaku positif anak autis dalam lingkungan. Keempat, meningkatkan kemampuan anak dan mendukung kemampuan komunikasi anak autis. Kelima, membentuk kemandirian anak dan mendukung kemampuan dasar akademis anak autis. Keenam, menyediakan informasi dan dat anak autis di Indonesia. Ketujuh, membuat standarisasi atau model perancangan anak autis (diagnostic, asesmen, dan intervensi). Kedelapan, melaksanakan asesmen dan diagnostic. Kesembilan, menyelenggarakan model-model intervensi dini. Kesepuluh, menyelenggarakan pelatihan bagi calon asesor, terapis pendamping pendidik dan tenaga kependidikan. Kesebelas, menyelenggarakan konsultasi (penanganan anak dan program). Keduabelas, menyelanggarakan model Kelompok Penunjang. Ketigabelas, membentuk parents support group/parent support community dan subbling support group.

Pelayanan bagi penyandang autisme di PLA Kota Metro dilakukan secara terpadu, di mana setiap terapis dan tenaga pendidik mempunyai tugas untuk mendampingi setiap penyandang autis, satu orang anak autis didampingi satu tenaga terapis atau intervensi dan tenaga pendidik yang biasa di sebut "shadow". Pelayanan tersebut dilakukan supaya mendapatkan hasil yang maksimal berupa kesiapan anak autis untuk melanjutkan pendidikan

Pola pengembangan potensi kecerdasan
emosional Dan spiritual anak penyandang
autisme


secara norma di lembaga-lembaga pendidikan formal, dan siap bergaul menyesuaikan dengan lingkungan sosial dan keluarganya. Tidak jarang sebenarnya penyandang autis dalam proses terapinya, mereka sebenarnya adalah siswa-siswa yang masih aktif di sekolah-sekolah formal, mulai TK, SD, hingga SMP. Layanan terapi yang dilakukan oleh para terapi di PLA Metro dilakukan secara individual bukan dalam kelas klasikal, hal ini yang membedakan peralakuan yang diberikan dengan anak yang normal, karena mereka adalah ABK (Anak Berkebutuhan Khusus), maka terapinya juga spesifik. Bahkan terkadang satu anak penderita autis perlu penanganan 2 orang terapis, tergantung dati tingkat kesulitan yang dihadapinya.

Pusat Layanan Autis (PLA) Kota Metro mempunyai komitmen untuk membantu warga yang mempunyai keluarga yang menderita autisme bukan hanya di kalangan warga kota Metro, tapi juga menerima pelayanan untuk keluarga di seluruh wilayah terdekat dari kota Metro. Hal ini terbukti banyaknya warga yang sudah mendaftar untuk mengikuti program-program yang diselenggarakan PLA Kota Metro. Pelayanan yang diberikan oleh PLA Kota Metro memang menggunakan pola pergantian setiap beberapa bulan program pelatihan, kemudian diberikan kesempatan lagi bagi warga untuk mendaftarkan anak-anaknya secara bergantian dalam masa waktu yang telah ditentukan, rata-rata lama proses pembinaan anak autis di PLA Kota Metro selama 8 bulan, kemudian diteruskan oleh angkatan berikutnya.

Metode yang digunakan untuk mengembangkan kecerdasan intelektual, emosional dan spiritual penyandang autis di PLA Kota Metro antara lain dengan menggunakan secara intensif beberapa metode yang khas yang biasa digunakan untuk memberikan terapi bagi penyandang autisme, antara lain terapi perilaku, terapi okupasi, terapi integrasi sensor, terapi wicara, terapi snoezelen (multisensory therapy), remedial terapi, terapi brain gym, biomedik terapi dan mediamentosa. Metode penanganan anak autis di PLA Kota Metro, biasa disebut juga dengan metode intervensi.

Secara umum penanganan anak autis di PLA Metro menggunakan teknik atau metode ABA (Applied Behavior Analysis) atau tatalaksana perilaku. Mekanisme ABA dengan mengamati perilaku (behavior) yaitu semua tingkah laku atau tindakam atau kelakuan seseorang yang dapat dilihat dan diamati serta didengar atau dirasakan oleh orang lain atau diri sendiri. Dalam pelaksanaan ABA dilakukan dengan dua strategi. Pertama, Discrete Trial Training (DDT) yaitu memecah setiap keterampilan yang belum dimiliki oleh anak ke dalam

Pola pengembangan potensi kecerdasan
$\begin{aligned} & \text { emosional Dan spiritual anak penyandang } \\ & \text { autisme }\end{aligned}$


bentuk keterampilan yang lebih kecil atau sederhana. Misalnya seorang anak diberi instruksi :"Ambil Gelas kuning di atas meja”. Kedua, menggunakan Reinforcement (imbalan/penguatan) bila anak bisa melakukan instruksi atau perintah yang diberikan, maka anak diberi imbalan yang dia suka (Depdiknas, 2002:3). Sedangkan materi pelajaran untuk anak autis diarahkan untuk memberikan bekal berupa suatu keterampilan atau kemampuan yang dibutuhkan untuk mencapai kesiapan, serta kemandirian sebagai bekal hidup dalam masyarakat sekitarnya. (Rudi Sutadi, 2003:78). Kemudian lebih dari itu, diharapkan anak autis akan mampu bersosialisasi dengan lingkungan sosial yang normal dan bekerja sesuai dengan kemampuannya. Secara umum kemampuan belajar anak autis mengembangkan kemampuan antara lain; program kesiapan, keterampilan meniru, keterampilan bahasa reseptif, keterampilan bahasa ekspresif, keterampilan pra-akademis, keterampilan bina diri, keterampilan sosialisasi, kesiapan bersekolah (Maurice, 1996:79).

Terapi ABA (Applied Behavior Analysis) tersebut dalam tataran tertentu menunjukkan beragam hasil yang mengindikasikan bahwa anak autis masih dapat dirubah perilakunya seperrti anak-anak normal yang lainnya. Bahkan tidak jarang menunjukkan anak autis perilaku dan kemampuan akademiknya tidak kalah dengan anak normal, hal ini kemungkinan berkaitan erat dengan beberapa faktor. Pertama, Berat Ringannya derajat kelainan, semakin berat derajar kelainan dan jenis kelainan perilakunya semakin sulit untuk "kembali" normal. Dan anak autis sekalipun berada pada derajat yang ringan ia perlu penanganan yang tepat. Kedua, Usia anak pertama kali ditangani secara benar dan teratur. Idelanya usia anak pertama kali ditangani adalah 2-3 tahun, pada usia ini perkembangan otak paling cepat. Namun bukan berarti yang berusia lebih dari 3 tahun harus dibiarkan. Mereka tetap memerlukan penanganan yang benar (khusus) sekalipun sudah melampaui usia ideal. Ketiga, Intensitas Penanganan, pola 40 jam per minggu adalah pola minimal untuk penanganan anak dengan teknik dan metode yang benar. Pola ini bisa dilakukan di sekolah dan dilanjutkan di rumah. Keempat, IQ anak, makin cerdas seorang anak, akan makin cepat dia menangkap materi yang diberikan. Namun perlu diingat bahwa kecerdasan emosional anak juga harus selalu diperhatikan , mengingat pengendalian emosi anak pada anak autis sangat minim. Diperkirakan 20-25\% anak autis memiliki IQ normal atau bahkan di atas rata-rata. Kelima, keutuhan Pusat bahasa di Otak, pusat bahasa di lobus parietalis kiri, apabila mengalami kerusakan maka anak akan

Pola pengembangan potensi
emosional Dan spiritual anak penyandang $\begin{aligned} & \text { Zainal Abidin, Isti Fatonah dan Linda } \\ & \text { autisme }\end{aligned}$


kesulitan berkata-kata (Juandanobo:2000).

Disamping terapi terapi perilaku atau sering disebut terapi dengan menggunakan metode ABA dalam penanganan anak autis, terdapat pula beberapa metode terapi autisme yaitu:, terapi Wicara, terapi Bermain, terapi Fisik, terapi Sosial, terapi Visual, terapi Okupasi, Biomedik treatment, Sensori integration, terapi musik, dan terapi perkembangan. Jenis-jenis terapi ini diberikan sesuaia dengan tingkatan masing-masing anak autis dalam skala autisnya yang berbeda-beda. Masing-masing terapi yang diberikan juga mempunyai orientasi yang berbeda- beda yakni: Terapi Wicara, Terapi Bermain, Terapi Fisik, Terapi Kemampuan Sosial, Terapi Perkembangan, Terapi Okupasi, Terapi Visual, Terapi Sensori Integrasi, Terapi Perilaku, Terapi Biomedical.

Jenis-jenis terapi dalam pengembangan kecerdasan emosional dan spiritual penyandang autis di PLA Kota Metro dapat di petakan dalam bentuk tabel berikut:

\section{Jenis-Jenis Terapi Pengembangan Kecerdasan Emosional dan Spiritual}

\begin{tabular}{|l|l|l|}
\hline No & \multicolumn{1}{|c|}{ Jenis Terapi } & \multicolumn{1}{c|}{ Manfaat Terapi } \\
\hline 1 & $\begin{array}{l}\text { Terapi Perilaku } \\
\text { (behavior } \\
\text { Therapy) }\end{array}$ & $\begin{array}{l}\text { Jenis terapi ini merupakan intervensi perilaku anak dalam rangka } \\
\text { peningkatan pemahaman dan kepatuhan anak terhadap aturan } \\
\text { agar perilaku anak lebih adaptif dalam lingkungan }\end{array}$ \\
\hline 2 & Terapi Okupasi & $\begin{array}{l}\text { Terapi ini dibeikan untuk dasar anak dalam hal kemandirian } \\
\text { dalam ADL (aktifitas kehidupan sehari-hari), kemampuan } \\
\text { koordinasi motorik kasar dan motorik halus, kontrol diri, } \\
\text { kognitif, knang } \\
\text { pemahaman dan kemampuan konsentrasinya }\end{array}$ \\
\hline 3 & $\begin{array}{l}\text { Terapi Integrasi } \\
\text { Sensori (Sensory } \\
\text { Integration } \\
\text { Therapy) }\end{array}$ & $\begin{array}{l}\text { Terapi ini merupakan aktivitas yang dapat merangsang koneksi } \\
\text { sinaptik yang lebih kompleks, dengan demikian bisa } \\
\text { meningkatkan } \\
\text { kapasitas untuk belajar. }\end{array}$ \\
\hline
\end{tabular}




\begin{tabular}{|c|c|c|}
\hline 4 & Fisioterapi & $\begin{array}{l}\text { Terapi ini diberikan bagi anak yang mengalami gangguan } \\
\text { perkembangan motorik dan tahapan perkembangan motoriknya, } \\
\text { misalnya anak yang mengalami keterlambatan kemampuan } \\
\text { duduk, berdiri dan berjalan }\end{array}$ \\
\hline 5 & Terapi Wicara & $\begin{array}{l}\text { Terapi ini diberikan bagi anak yang mengalami perkembangan } \\
\text { bahasa bicara yang terlambat, berupa gangguan pemahaman } \\
\text { (reseptif) maupun gangguan pengujaran (ekspresif). Terapi ini } \\
\text { juga bertujuan agar anak dapat berkomunikasi secara optimal di } \\
\text { masyarakat berdasarkan modalitas yang dimiliki oleh anak. }\end{array}$ \\
\hline 6. & $\begin{array}{l}\text { Terapi } \\
\text { Snoezelen } \\
\text { (Multisensory } \\
\text { Therapy) }\end{array}$ & $\begin{array}{l}\text { Ini merupakan jenis terapi multisensory, di mana terapi } \\
\text { menggunakan aktifitas yang dirancang mempengaruhi sistem } \\
\text { sensori primer (ssp) melalui stimuli yang cukup pada system } \\
\text { sensori primer dan sensori sekunder dalam ruang multi sensori. } \\
\text { Stimuli primer/reseptor 1/reseptor sensori eksternal yang akan } \\
\text { diberikan berupa visual, auditori, olfactory/penciuman, } \\
\text { gustatory/ pengecapan/tactile/masalah sensor raba, stimuli } \\
\text { sekunder/reseptor } 2 / \text { reseptor sensori internal yang akan diberikan } \\
\text { adalah berupa keseimbangan dan } \\
\text { proprioceptove/rasa sendi. }\end{array}$ \\
\hline 7 & $\begin{array}{l}\text { Remedial } \\
\text { Therapy }\end{array}$ & $\begin{array}{l}\text { Terapi ini berfokus pada sikap belajar dan penuntasan } \\
\text { pemahaman peserta layanan terhadap pelajaran di sekolah, } \\
\text { seperti pemahaman anak autis terhadap pelajaran bahasa, } \\
\text { matematika, science dan lainnya. Terapi ini diberikan pada } \\
\text { anak autis yang sudah mendapatkan layanan pendidikan }\end{array}$ \\
\hline 8 & $\begin{array}{l}\text { Terapi Brain } \\
\text { Gym }\end{array}$ & $\begin{array}{l}\text { Terapi ini terdiri dari serangkaian latihan gerak sederhana untuk } \\
\text { memudahkan kegiatan belajar, rangkaian kegiatan yang cepat, } \\
\text { menarik dan dapat meningkatkan semangat saat beraktifitas. } \\
\text { Program ini sangat membantu dalam hal belajar di sekolah dan } \\
\text { tuntutan penyesuaian kegiatan sehari-hari, sehingga dapat } \\
\text { memaksimalkan kerja otak kanan dan otak kiri }\end{array}$ \\
\hline 9 & $\begin{array}{l}\text { Terapi Biomedik } \\
\text { dan } \\
\text { Medikamentosa }\end{array}$ & $\begin{array}{l}\text { Terapi jenis ini berfokus pada pengoptimalan fungsi-fungsi pada } \\
\text { otak yang disebabkankan oleh gangguan metabolisme. Terapi ini } \\
\text { dilaksanakan oleh dokter spesialis, dengan penguasaan tentang } \\
\text { penanganan anak autis. Di samping itu dokter juga akan } \\
\text { melakukan terapi obat-obatan (medikamentosa) sesuai } \\
\text { kebutuhan peserta layanan gejala yang bisa dihilangkan seperti } \\
\text { gejala hiperaktivitas yang berat, menyakiti diri sendiri, } \\
\text { menyakiti orang lain, merusak dan gangguan tidur. }\end{array}$ \\
\hline
\end{tabular}




\begin{tabular}{|c|l|l|}
\hline 10 & $\begin{array}{l}\text { Terapi Diet } \\
\text { Makanan }\end{array}$ & $\begin{array}{l}\text { Terapi ini dilaksanakan bagi anak dengan alergi tertentu. Terapi } \\
\text { diet meliputi mengurangi atau membatasi bahkan meniadakan } \\
\text { konsumsi dari casein, glutein dan gula. Terapi ini dilaksanakan } \\
\text { oleh dokter spesialis anak atau psikiater yang } \\
\text { menguasai pengetahuan tentang diet anak autis }\end{array}$ \\
\hline 11 & $\begin{array}{l}\text { Hidroterapi/ } \\
\text { Berenang }\end{array}$ & $\begin{array}{l}\text { Terapi yang menggunakan media air dan kolam yang berguna } \\
\text { untuk menangani gangguan sensori tactile, pobia air, gangguan } \\
\text { konsentrasi gangguan motorik (otot dan sendi) dan } \\
\text { keseimbangan } \\
\text { motorik. Di perlukan kolam renang minimal 5x10m persegi, } \\
\text { dengan kedalaman 0,5 meter, 1 meter dan 1,5 meter }\end{array}$ \\
\hline 12 & $\begin{array}{l}\text { Outdoor } \\
\text { Therapy }\end{array}$ & $\begin{array}{l}\text { tetapi sudah pernah mengalami terapi SI (Sensori Integrasi). } \\
\text { Terapi Outdoor dilakukan secara berkelompok, dan dibutuhkan } \\
\text { lahan sekitar 10x20meter persegi, dengan sarana seperti ruang SI } \\
\text { namun dalam ukuran yang lebih besar, panjang, dan tinggi. }\end{array}$ \\
\hline
\end{tabular}

Pola pengembangan kecerdasan emosional dan spiritual pada penyandang autis di PLA Kota Metro dilakukan dengan beberapa pola:

\section{Pola Pengembangan Kecerdasan Emosional}

Tingkat IQ atau kecerdasan intelektual seseorang umumnya tetap sedangkan EQ (kecerdasan emosi) dapat terus ditingkatkan. Dalam hal peningkatan kecerdasan emosi memang berbeda dengan peningkatan kecerdasan intelektual (IQ). Kecerdasan intelektual pada umumnya tidak berubah selama hidup manusia. Dengan begitu kecerdasan kognitif atau intelektual pada umumnya hampir tidak bisa berubah, sedangkan kecakapan atau kecerdasan emosi dapat dipelajari kapan saja. Tidak peduli orang itu pemalu, tidak peka, pemarah, kikuk, atau sulit bergaul dengan orang lain sekalipun, dengan motivasi dan usaha yang benar, kita mampu mempelajari serta menguasai kecakapan emosi tersebut (Agustian, 2001:274).

Secara definitif menurut Ari Ginanjar Agustian (2001:276) menjelaskan bahwa kecerdasan emosi adalah kemampuan merasakan, memahami secara efektif, menerapkan daya dan kepekaan emosi sebagai sumber energy, informasi, koneksi dan pengaruh manusia. Bahkan emosi adalah bahan bakar yang tak tergantikan bagi otak agar mampu melakukan penalaran. Emosi dapat menyulut kreativitas, kolaborasi, inisitaif, dan transformasi, sedangkan penalaran logis berfungsi mengantisipasi dorongan-dorongan keliru, untuk kemudian menyelaraskannya dengan proses kehidupan dengan sentuhan manusiawi. Di

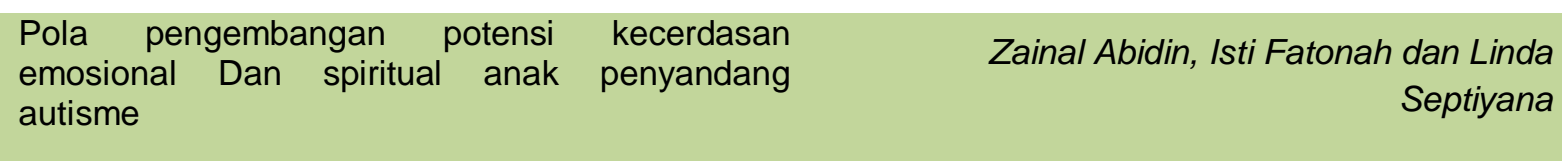


samping itu, emosi juga menjadi kekuatan penggerak. Dan wata dasar dan nilai-nilai sesorang dalam hipdup ini tidak berakar pada IQ tetapi pada kemampuan emosional.

Pola pengembangan kecerdasan emosional pada penyandang autisme secara teoritis dapat dilakukan dengan mengembangkan potensi batini setiap anak autis yang dapat mendorong untuk melakukan kebajikan, melalui pembiasaan dan pelajaran akhlak yang mulia. Strategi pengembangan kecerdasan spiritual bagi penyandang autisme di PLA Kota Metro antara lain. Pertama, pengelolaan Diri dengan cara selalu perlu mempertimbangkan pemahaman tentang diri yang selalu berada dan berkembang dalam konteks sosial, di mana pengeloolaan diri mengandung arti kemampuan seseorang dalam mengelola diri dan perasaan yang dialami. Dalam prakteknya penyandang autis mulai diperkenalkan dengan pelajaranpelajaran yang sederhana untuk dapat mengelola perasaannya secara personal. Proses pengenalan diri ini sangat lama dan membutuhkan kesabaran yang luar biasa yang dilakukan terapis (pendidik) kepada setiap anak- anak penyandang autis di PLA Kota Metro.Kedua, kemampuan Kesadaran diri, dengan memberikan keterampilan membangun kesadaran diri pada penyandang autisme berupa kasedaran identitas diri (jati diri) secara individu dan personal, dalam kedirian masing-masing anak, sesuai karakter pribadi, menjadi diri sendiri bukan menjadi orang lain. Proses membangun kesadaran diri ini tidak mudah membutuhkan waktu yang cukup lama dan bervariasi sesuai dengan tingkatan kondisi emosi penyandang autis yang beragam. Ketiga, kemampuan untuk Memotivasi diri, kemampuan ini berguna unruk mencapai tujuan jangka panjang, mengatasi setiap kesulitan yang dialami bahkan untuk menghadapi kegagalan yang terjadi. Kemampuan memotivasi diri juga bisa menumbuhkan kepercayaan diri dan optimisme. Di samping pembelajaran yang berorientasi pada pengenalan diri, terapi selenjuntnya untuk mengembangkan kecerdasan spiritual anak penyandang autisme di PLA Kota Metro, dilakukan dengan memberikan kepercayaan diri dan semangant yang tumbuh secara intrinsik dari dalam anak-anak penyandang autis itu sendiri, maupun berupa motivasi ekstrinsik anak autis yang ikut dalam program penanganan autis di PLA Kota Metro. Para terapis secara aktif memberikan motivasi bagi anak-anak autis untuk semangat dalam belajar supaya tidak pesimis dengan masa depannya. Keempat, membangun Empati, sama dengan teori kecerdasan emosional, membangun empati juga menjadi bagian dari teori kecerdasan spiritual. Empati dibangun dari kesadaran diri dan dengan memposisikan diri

Pola pengembangan potensi
emosional kan spiritual anak penyandang $\begin{array}{r}\text { Zainal Abidin, Isti Fatonah dan Linda } \\ \text { autisme }\end{array}$


senada, serasa dengan emosi orang lain, akan membantu seseorang mampu membaca dan memahami perasaan orang lain. Melatih anak autis tidak semudah melatih anak yang normal, dibutuhkan kesabaran yang ekstra, terutama berkaitan dengan usaha membangun empati. Karena permasalahan utama autis adalah ketidakpedulian dan ketidakpekaan mereka terhadap lingkungan sekitar, akibat pembawaan mereka yang asik dengan dunianya sendiri. Dalam kaitan ini terapis di PLA Kota Metro, memberikan pelatihan untuk mulai berempati dengan sesame teman-teman sebaya dan lingkungan mereka, dengan jalan melatih mereka dengan memberikan stimulant dalam beberapa aktifitas belajar yang bisa membangun kesadaran dan kepedulian sosial. Kelima, keterampilan Sosial, merupakan kemampuan untuk berinteraksi dengan orang lain dalam konteks sosial dengan cara-cara khusus yang dapat diterima oleh lingkungan dan pada saat yang sama dapat menguntungkan diri atau orang lain. Untuk penyandang autis di PLA Kota Metro, keterampilan sosial diberikan dengan melatih anakanak autis cara-cara berinteraksi dengan guru (terapis) dan berkomunikasi dengan lingkungan belajar mereka sejak dini, di samping melatih kemampuan bicara melalui terapi wicara.

Pola yang dilakukan dalam pengembangan kecerdasan emosional penyandang autis pada PLA (Pusat Layanan Autisme) kota Metro telah mengikuti pola pengembangan kecerdasan emosi (emotional intelligence) yang terkenal dikemukakan Daniel Goleman. Dengan mengikuti beberapa tahapan, dengan harapan agar penyandang autis mempunyai kecerdasan emosional. Tahapan tersebut secara garis besar ada lima tahapan, yaitu kesadaran diri (self-awareness), pengaturan diri (self-regulation), motivasi (motivation), empati (empathy), dan keterampilan sosial (social skill). Tiga yang pertama, yakni kesadaran diri, pengaturan diri, dan motivasi lebih terkait dengan kecerdasan intrapersonal dalam pandangan Howard Gardner, sang pencetus kecerdasan majemuk (multiple intelligences). Sementara itu, dua yang terakhir, yakni empati dan keterampilan sosial lebih terkait dengan "kecerdasan interpersonal" dalam pandangan Gardner. Sedangkan Ari Ginanjar Agustian (2001:8) menyatakan bahwa kecerdasan emosional terefleksi dalam kemampuan pribadi dan sosial yang menjadi kemampuan utama keberhasilan seseorang. Kecerdasan emosional juga dengan kemampuan merasa seseorang, dan kejujuran pada suara hati. Kecerdasan emosional secara faktual tidak bisa dipisahkan dengan pengembangan kecerdasan spiritual manusia, kedua kecerdasan tersebut berkaitan satu dengan lainnya. Karena keduanya mengandung

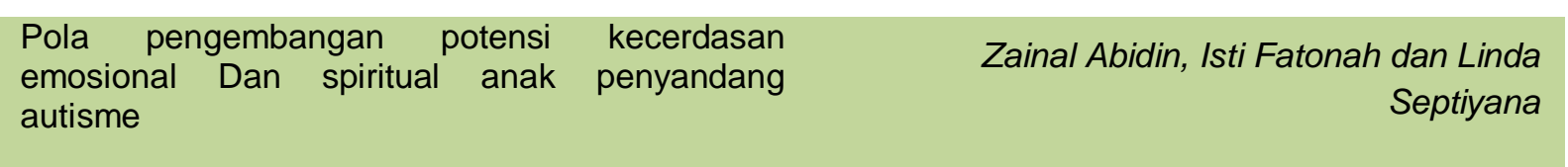


keseimbangan kemampuan seseorang dengan relasi antara sesama manusia dan relasi dengan tuhannya.

Disamping itu untuk mengembangkan potensi kecerdasan emosional panyandang autis di PLA Kota Metro juga menerapkan beberapa strategi sebagaimana yang digunakan untuk penguatan kecerdasan emosinya. Upaya-upaya tersebut pada umumnya digunakan dalam membentuk kepribadian muslim dan akhlak mulia (akhlak al-Karimah). Strategi tersebut berkaitan satu dengan lainnya dalam pengembangan kecerdasan emosional dan kecerdasan spiritual sekaligus, contohnya memberikan beberapa kecakapan emosi dan spiritual secara terintegrasi. Pembiasaan dan pelatihan sikap konsistensi (istiqamah), kerendahan hati (tawadlu'), berusaha dan berserah diri (tawakal), ketulusan/sincerity (ikhlash), totalitas (kaffah), keseimbangan (tawazun) dan integritas dan penyempurnaan diri (Agustian, 2001:276)

\section{Pola Pengembangan Kecerdasan Spiritual}

Pengembangan kecerdasan spiritual didasari pada sebuah teori yang berasal dari beberapa penelitian. Pertama, penelitian, yang dilakukan oleh para ahli saraf Michael Persinger pada tahun 1990 an awal dan riset yang dilakukan oleh VS Ramachandran tahun 1997 bersama timnya dari Universitas California, yang mendeteksi adanya God Spot dalam otak manusia, dan telah terbentuk (built in) sebagai pusat spiritual yang terletak di bagian depan otak. Kedua, berdasarkan hasil penelitian ahli saraf dari Austria, Wolf Singer tahun 1990-an, dalam makalahnya yang bertopik "The Binding Problem" menujukkan dan menemukan bahwa terdapat proses saraf dalam otak manusia yang terkonsentrasi pada usaha untuk menyatukan serta memberi makna dalam pengalaman hidup manusia. Sebuah jaringan saraf yang secara literal "mengikat" pengalaman kita secara bersama untuk hidup lebih bermakna. God Spot itu sendiri merupakan fitrah pada setiap manusia secara universal, berupa potensi spiritual yakni kesadaran tentang kepercayaan adanya Tuhan sebagai pusat segala kehidupan dan sebagai tempat kembali. Dalam persepektif agama Islam potensi "God Spot" manusia dapat dikembangkan dengan mengasah potensi ruhaniyah dan mengasahnya melalui amaliah ibadah yang secara sikap ikhlas dilakukan dan ketundukan sepenuhnya terhadap ketentuan Allah SWT, dan dalam rukun imam di sebut sebagai Iman kepada Qodho dan Qodar, di samping iman kepada eksistensi Allah SWT yang Maha Esa sebagai rukun Islam

Pola pengembangan potensi
emosional Dan spiritual anak penyandang $\begin{aligned} & \text { Zainal Abidin, Isti Fatonah dan Linda } \\ & \text { autisme }\end{aligned}$


yang pertama.

Dalam perspektif pengembangan kecerdasan spiritual, istilah "God Spot" (Titik Tuhan), secara praktik bisa diterapkan dalam penanganan penyandang autisme. Titik Tuhan memainkan peran biologis yang menentukan dalam pengalaman spiritual. Namun demikian, Titik Tuhan bukan merupakan persayaratan mutlak dalam kecerdasan spiritual. Perlu adanya integrasi antara seluruh bagian otak, seluruh aspek dari bagian otak, seluruh segi kehidupan. Artinya kecerdasan spriritual tetap membutuhkan unsur lainnya berupa sel-sel otak manusia di samping faktor berupa intervensi nilai-nilai ketuhanan yang dibawa oleh setiap manusia. Dalam mengefektifkan potensi "God Spot" yang dimiliki oleh penyandang autis di PLA Kota Metro, materi pembinanannya diorientasikan pada pengenalan terhadap ajaran agama dengan mengawali setiap doa yang dipanjatkan kepada Allah SWT, yang dilakukan oleh terapis yang langsung membimbing setiap penyandang autis, pada awal dimulainya terapi dalam pengembangan emosi dan spiritual para penyandang autis.

Pembiasaan doa ini juga sebaiknya dilakukan oleh orang tua penyandang autis, untuk mempercepat pemulihan-pemulihan kejiwaan dan emosionalitas, spiritualitas, termasuk dalam intelektualitas penyandang autis, supaya upaya-upaya yang dilakukan bisa mendapatkan hasil yang efektif. Dalam kontek ini pengembangan kecerdasan spiritual penyandang autisme di PLA Kota Metro dibutuhkan juga sentuhan-sentuhan rohani melalui pendekatan agama Islam, untuk menenangkan jiwa anak-anak penyandang autis tersebut, melalui doa-doa yang diajarkan selama terapi, dan memperkenalkan ayat-ayat pendek dalam al-Qur'an untuk memperkenalkan dimensi religious yang diharapkan terbangun dalam proses terapi tersebut.

Sesuai dengan teori yang dikembangkan oleh tokoh ESQ Indonesia, Ari Ginanjar Agustian, kecerdasan spiritual merupakan landasan yang diperlukan untuk memfungsikan IQ dan EQ secara efektif. Menurut Ari Ginanjar, SQ merupakan kecerdasan tertinggi manusia. Dalam ESQ kecerdasan Spiritual merupakan kemampuan untuk memberi makna spriritual terhadap pemikiran, perilaku dan kegiatan serta mampu menyinergikan IQ, EQ dan SQ secara komprehensif dan transedental. Dengan demikian kecerdasan spiritual adalah kecerdasan untuk menghadapi persoalan makna, berupa kecerdasan untuk menempatkan perilaku dan hidup kita dalam konteks makna yang lebih luas dan kaya, yang merupakan kecerdasan untuk menilai bahwa tindakan atau jalan hidup seseorang lebih bermakna dibandingkan dengan yang

Pola pengembangan potensi $\begin{gathered}\text { kecerdasan } \\ \text { emosional Dan spiritual anak penyandang } \\ \text { autisme }\end{gathered}$


lain (Agustian:2001). Pada akhirnya sebenarnya mengembangkan kecerdasan emosional (EQ) dan kecerdasan spiritual (SQ) sangat berkaitan dengan teori dan praktek rukun Iman dan rukun Iman serta Ihsan secara bersinergi dan terintegrasi dalam kepribadian seseorang, bahkan dalam pengembangan kecerdasan intelektual (IQ) sekalipun.

Strategi pengembangan kecerdasan emosional dan spiritual pada penyandang autis dilakukan secara simultan dan diterapkan sesuai dengan prosedur-prosedur yang ditetapkan dalam penganganan penyandang autis dengan pendekatan yang manusiawi untuk memanusiakan manusia, apalagi terhadap anak-anak yang berkebutuhan khusus, seperti anakanak autis yang sangat membutuhkan perhatian yang ekstra ketat. Pengembangan kecerdasan emosional (EQ) dan kecerdasan Spiritual (SQ) pada penyandang autisme diorientasikan untuk mencapai kedewasaan intelektual dan emosional, serta mengembakan potensi spiritual sekaligus potensi sosial penyandang autis. Tentunya sangat berbeda perlakuan antara anakanak normal dengan anak penyandang autis dalam pengembangan kecerdasan emosional dan kecerdasan spritualnya. Bagi anak berkebutuhan khusus (ABK) penangannya lebih membutuhkan kesabaran dan waktu yang agak lama, di bandingkan dengan pengembangan EQ dan SQ pada anak-anak yang normal, karena pada umumnya perilaku (behavior) anak autis dan anak-anak yang normal agak berbeda, bahkan bisa dikatakan sangat berbeda. Tetapi melalui beberapa terapi dan pola pengembangan kecerdasan emosional dan spiritualnya, diharapkan mampu menuju pada kondisi normal dan mulai berkurang penderitaan yang diakibatkan oleh autisme yang mereka alami.

\section{SIMPULAN}

Berdasarkan pembahasan dari beberapa bab yang telah dilakukan dapat ditemukan beberapa temuan penting dalam penelitian ini yang berupa simpulan penelitian. Temuan tersebut yaitu: pertama : Pengembangan kecerdasan emosional dan spiritual anak penyandang autisme dilakukan secara bertahap sesuai dengan kadar gejala autis yang mereka alami. Hal ini disebabkan secara realitas terdapat perbedaan masing-masing penyandang autis dilihat dari berat dan ringan gejala autis yang ada di PLA Kota Metro. Penyandang autis juga mempunyai berbagai tipe-tipe yang berbeda-beda, sehingga penanganan autis harus dilakukan secara terpisah melalui tenaga terapi intervensi dan dilakukan oleh Shadow (pendidik/terapis) yang berbeda- beda. Kedua : Pola pengembangan kecerdasan emosional dan spiritual penyandang

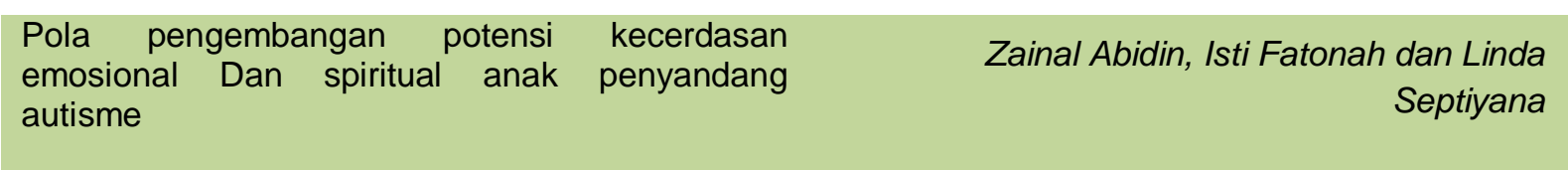


autis dilakukan dengan pola terapi yang beragam antara lain dengan menggunakan terapi ABA (Applied Behaviour Analysis) atau tatalaksana perilaku, terapi okupasi, fisioterapi, terapi wicara, Remedial Teraphy, Multisensory Therapy, terapi diet makanan, terapi biomedik, terapi berenang (hidrotherapy), terapi brain gym, dan terapi outdoor, dan sebagainya. Ketiga: Secara faktual karena terdapat perbedaan ciri anak autis dengan anak normal dalam berbagai aspek perilaku dan sikap serta potensi kecerdasan intelektual, emosional, spiritual dan sosialnya, sehingga pola pengembangan kecerdasan dan spiritual bagi penyandang autis juga mengindikasikan perbedaan pola. Bahwa penyandang autis terlihat sangat lambat dan perlu perhatian utama dan kesabaran dalam pengembangan kedua kecerdasan tersebut, untuk dapat mencapai hasil optimal yang diharapkan. Pendekatan dalam pengembangan kecerdasan emosional bisa dilakukan dengan pola pendekatan religious dengan pembiasaan hidup dengan mengajari akhlak mulia, dan sifat-sifat istiqomah, rendah, tawadlu dan sebagainya. Terdapat hubungan yang erat dengan pola pengembangan spiritual bagi penyandang autisme di PLA Kota Metro, dengan melakukan terapi yang berorientasi pada pengembangan dimensi spiritual dengan pembiasaan kesadaran tentang adanya Tuhan (God Spot), dengan membiasakan setiap awal pembelajaran dengan berdoa yang dilakukan oleh tenaga pendidik atau tenaga intervensi dan anak-anak penyandang autis. Ini dalam konteks pengembangan kecerdasan spiritual merupakan refleksi pengamalan rukun Iman, rukun Islam, dan Ihsan sekaligus pada penyandang autis.

\section{DAFTAR PUSTAKA}

Adelle Jameson Tilton. (2013). Panduan Lengkap Orang Tua Dengan Anak Autisme, Malaysia: Sabah Press.

Adriana S. Ginanjar. (2012) Panduan Praktis Mendidik Anak Autis, Jakarta: Dian Rakyat, Resipatori UI.

Andreas Hartono. (2009). EQ Parenting Cara Praktis Menjadi Orangtua Pelatih Emosi, Jakarta: Gramedia.

Agus Nggermanto. (2005). Quantum Quotient (Kecerdasan Quantum), Bandung: Nuansa.

Ari Ginanjar Agustian. (2003). Rahasia Membangkitkan ESQ Power Sebuah Inner Journey Malalui Ikhsan, Jakarta: Agra.

Ari Ginanjar Agustian. (2001). ESQ Rahasia Sukses Membangun Kecerdasan Emosi dan Spritual, The ESQ Way 165, Jilid 1,Jakarta: Arga Tilanta.

Burhan Bungin (ed). (2010). Metodologi Penelitian Kualitatif; Aktualisasi Metodologis ke Arah Ragam Varian, Jakarta: Raja Grafindo Persada.

Dana Zohar dan Ian Marshall. (2000), SQ (Spiritual Intellegence), The Ultimate Intellegence,

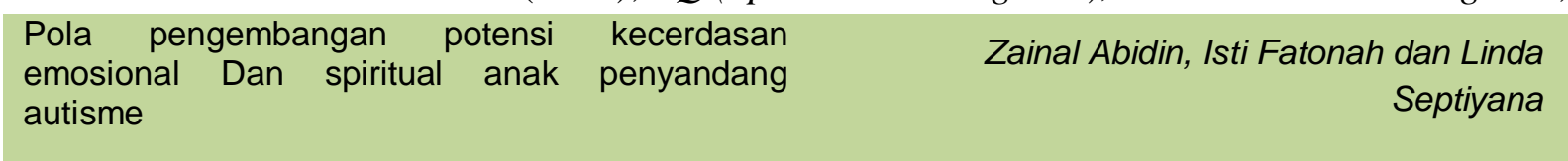


London: Bloomsbury.

Daniel Goleman. (2002). Working With Emotional Intelligence, Jakarta: Gramedia.

Deded Koswara. (2013). Pendidikan Anak Berkebutuhan Khusus Autis, Bandung: Luxima. Depdiknas. (2002). Pedoman Pelayanan Pendidikan Bagi Anak Autis, Jakarta.

Faisal Yatim Dimah. (2002), Autisme Gangguan Jiwa pada Anak-Anak, Jakarta: Yayasan Obor.

Gayatri Pamoedji Iskandar. (2010), Pertanyaan dan Jawaban Seputar Autisme, Jakarta: Empati Press.

Hamzah B Uno. (2008). Orientasi Baru Dalam Psikologi Pembelajaran, Jakarta: Bumi Aksara. Handojo. (2015). Autisme Pada Anak, Jakarta: BIP Gramedia.

J. Vredenbregt. (1981). Metode dan Teknik Penelitian Masyarakat, Jakarta: Gramedia.

Koentjaraningrat. (1990). Metode Penelitian Masyarakat, Jakarta: Gramedia.

Kogan et.al. (2009). Prevalence of Parent-Reported Diagnosis of Autism Spectrum Disorder Among Children in the US 2007, Pediatrics Jounal.

Klin Ami Jones Warren."Defining and Quantifying the Social Phenotype in Autism", American Jounal of Psychiatry h. 159: 895-908.

Lexy J. Meoloeng. (2002). Metodologi Penelitian Kualitatif, Bandung: Rosda Karya.

Linda Herawati Gunawan, dkk. (2015), Terapi Autisma dengan Metode Picture Exchange Communication System, Jakarta: Leutika Prio.

Maliki S. (2009). Manajemen Pribadi Untuk Kesuksesan Hidup, Yogyakarta: Kertajaya. Maurice C. (1996). Behavioral Invention for Young Children with Autism, Texas: Proed.

Monty P Satiadarma, Fidelis E. Waruwu. (2003). Mendidik Kecerdasan, Jakarta: Pustaka Populer Obor,

Rudy Sutadi dkk. (2003). Penatalaksanaan Holistik Autisme, Jakarta: FKUI. 